\title{
Re-humanising Coriolanus. Community and the ethical self
}

\section{$\alpha$ \\ Re-humanizando Coriolanus. comunidad y el ser ético}

\author{
María Luisa Pascual Garrido \\ Universidad de Córdoba, Spain
}

\section{ABSTRACT}

In this article I analyse subjectivity in Coriolanus taking as a starting point the traditional antagonism between essentialist humanism and cultural materialism. While mainstream humanism has approached Shakespeare's plays stressing the transcendental nature and autonomy of the subject, cultural materialism has challenged that assumption by underscoring the actual lack of freedom of the individual whose actual choices are determined not by the inherent nature of the hero but by social and political forces.

My aim is to try to bridge the gap between two seemingly divergent ways of understanding subjectivity by adopting a more sceptical form of humanism, which is based on both the acceptance of the limits and the vulnerability of human beings (Mousley 2007) and recent developments in communitarian theory and biopolitics (Nancy 1991, Agambem 1995, Butler 2006, Esposito 2012). I contend that Coriolanus is an embodiment of humanity, a singular being capable of making an ethical choice at the risk of his own death.

KEYWORDS: William Shakespeare, Coriolanus, subjectivity, humanity, ethical community, vulnerability, singularity of being.

\section{RESUMEN}

En este artículo se analiza la subjetividad en Coriolano tomando como punto de partida la tradicional discrepancia entre dos corrientes de pensamiento antagónicas: el humanismo esencialista y el materialismo cultural. Mientras que la crítica humanista más ortodoxa ha abordado las obras de Shakespeare insistiendo en la naturaleza transcendental y autónoma del sujeto, el materialismo cultural la cuestiona, negando en cambio la existencia de la libertad del individuo, cuyas decisiones vienen determinadas no tanto por la naturaleza o el carácter inherente del héroe sino más bien por factores externos al individuo tales como la presión social o política.

Mi propósito es intentar tender un puente entre dos formas aparentemente opuestas de concebir la subjetividad. Para ello adopto una versión más escéptica del humanismo ortodoxo sustentada, por una parte, en la afirmación de que las limitaciones y la vulnerabilidad son aspectos ineludibles de ser humano (Mousley 2007) y, por otra, en el reciente desarrollo de ciertas teorías sobre comunidad en el ámbito de la biopolítica (Nancy 1991, Agambem 1995, Butler 2006, Esposito 2012). A la luz de estos planteamientos, sostengo que el personaje de Coriolano es una justa encarnación de lo humano, un ser singular capaz de hacer una elección ética aun a riesgo de perder la propia vida.

PALABRAS ClAVE: William Shakespeare; Coriolano; subjetividad; humanidad; comunidad ética; vulnerabilidad; singularidad del ser.

\section{Introduction}

Readers and audiences are usually baffled about where the playwright's apparent sympathies lie in Coriolanus. Some critics have addressed this tragedy as a work that promotes a pro-republican ideology just emerging in the late sixteenth century, according to

\author{
(C) ederi 26 (2016: 85-107) \\ https://doi.org/10.34136/sederi.2016.4
}


which Shakespeare would side with the plebeians' struggle for sovereignty (Patterson 1989). ${ }^{1}$ Seen in this light, Coriolanus stands as an irritating symbol for absolutism, while the fact that the plebeians' grievances are voiced and the warrior is banished is interpreted as a sign of Shakespeare's progressive stance in politics. ${ }^{2}$ On the other hand, humanist criticism, with a firm belief in an essentialist conception of the individual, has generally focused on the character's assertion of individual subjectivity, arguing that the playwright conceived of the Roman warrior as "a noble, even a lovable, being" (Bradley 1904, 83). From this perspective, it is the unyielding nature of the Roman warrior against the strain of external forces what defines the character as truly admirable.

Most recent readings of this tragedy have been concerned with Shakespeare's advocacy for the rights of the commonality. Thus Andrew Hadfield analyses the playwright's engagement with reformist political theory and declares that "plays such as Coriolanus (1607-1608) and Pericles (1609) demonstrate the need to 'define civic virtue and create a sustainable balanced state'" $(2005,205)$. That republican thought as discussion of the commonwealth is a central issue in Coriolanus is evident in Menenius' fable of the belly, "touching the weal o'th'common" (1.1.134), and the detailed depiction of the canvassing process (2.3). It is the concept of "civic

\footnotetext{
${ }^{1}$ Patterson's "'Speak, Speak!': The Popular Voice and the Jacobean State" (1989, 12053) is one of the most convincing arguments following this line. Oliver Arnold also lists a number of contributions which view Coriolanus as the work of "a prescient liberal who championed the people" and "belie[ved] that Jacobean England, desperately needed to borrow from the strengths, as well as from the difficulties, of republican theory" $(2007,192)$.

${ }^{2}$ However, this pro-republican view is contested by critics who consider that Shakespeare is voicing contemporary anxieties over the changing political situation, with "a nascent class consciousness" threatening the political and social order and anticipating republicanism in England (Bliss 2010, 23). Taking into account Shakespeare's prosperity as a landowner by 1607, and the uprisings against enclosure as an obvious subtext for the play, it would be highly problematical to classify Shakespeare as a staunch supporter of extended civil rights. Indeed, Coriolanus' contempt of the plebeians (1.1.181-2) has been considered an echo of the author's allegedly hatred of the mob. Yet, as Hadfield notes, republican discourse was still quite contradictory in England after the long debate about Elizabeth's succession, so "republican thought could be used to defend as well as to attack the monarchy" (2005, 18).
} 
virtue" that seems relevant to critics hailing Shakespeare's purportedly republicanism in Coriolanus as well as in other works. ${ }^{3}$

Although political interpretations of the play have proved insightful, I do not intend to take the manifest socio-political conflict in Coriolanus as the central point of this essay. It is rather the problematic interpretation of subjectivity as self-sovereignty that I will address here.

When considering Coriolanus' nature and identity, critics seem to have adhered to either one of the following views. The first is based on the assumption that Coriolanus' sense of selfhood is stable and inherent to the character, as Coriolanus repeatedly asserts, and accordingly that his identity must be independently considered from whatever relationships the individual may establish with other members of the community. This is in line with A. C. Bradley's humanist interpretation, which asserts the free will and sovereignty of the subject regardless of social and political constraints. In contrast, the second type of reading considers that Coriolanus' nature and identity can only be defined in terms of the warrior's rapport with other beings, so it is understood to be politically and socially determined, particularly when class struggle is judged to be a pivotal question in the play. Therefore, in historicist readings like Jonathan Dollimore's in Radical Tragedy (1984), the discussion revolves around Coriolanus' assertion of his despotic will against the commonwealth and his failure to understand his role in the community by fully complying with his "civic" duties. As a result, the emphasis is on a concept of the subject as a relational, social being, whose identity cannot be understood as free from societal and political constraints. Although, I agree to a certain extent with Dollimore in his interpretation of Coriolanus' identity as the result of conflicting ideological forces and mechanisms of power, I will not exclusively pursue a cultural materialist reading of the play.

In this paper, my purpose is to bridge the gap between these apparently incompatible views on how subjectivity and, in particular, Coriolanus' nature have generally been interpreted.

\footnotetext{
${ }^{3}$ Hadfield focuses mainly on The Rape of Lucrece, Titus Andronicus, Julius Caesar and Hamlet as works distilling a complex republican discourse. Coriolanus is mentioned briefly as just another instance of Shakespeare's fascination with the Roman republic as a model for parliamentarism and political representation in the Jacobean era.
} 
Following Andy Mousley in Re-Humanising Shakespeare (2007), I will argue that a less self-assured humanist reading of Coriolanus is possible, one which includes a new definition of the human on the basis of lack and vulnerability. My analysis will also be informed by recent theory on community, one which adopts an ethical perspective.

Mousley deftly argues for the need to re-examine our understanding of literary humanism by broadening its scope. Acknowledging the prevalence of an essentialist humanism against which post-structuralist theory started reacting by the 1970s, Mousley grants the existence of an alternative, more distrustful humanist approach to literary texts which goes beyond the so-called "mainstream humanism." Liberal humanism as a critical practice was perceived to be based on "an inflated assumption that 'man' is the origin and source of meaning, of action, and of history" (Belsey 1980, 7). Yet, as Mousley points out, the humanist discourse that fosters the ideal of self-autonomy and human transcendence inspiring classical studies on Shakespeare's drama (Bradley's Shakespearean Tragedy, 1904), G. Wilson Knight (The Wheel of Fire, 1930; The Crown of Life, 1947) and H. C. Goddard (The Meaning of Shakespeare, 1951) represents a particularly optimistic conception of human nature. Historicism and cultural materialism emerged in clear antagonism to the "naive and uncritical" position of liberal humanism given the obvious existence of social and historical limitations determining subjective identity and defining human nature (Mousley 2007,14).

The postmodern version of humanism which Mousley advances does not take for granted an uncompromising belief in human freedom and self-sovereignty. In approaching Shakespearean texts, Mousley suggests a slightly different version of humanism, one based on the possibility "to articulate a belief in human nature, not in terms of hubristic transcendence but more humbly, as an acceptance of human limits" (Mousley 2007, 15). I find this approach quite suitable to analyse Coriolanus since much of the discussion in the play revolves around models of humanity and inhumanity. This new form of humanism acknowledges the sceptical challenge derived from post-modern theory and hence the need to redefine "the human" in an age of disbelief and uncertainty. The task is quite challenging since "the model of transcendence," which has certainly 
monopolised humanism, focuses on the ideal of human superiority and the infinite capacity of human beings for improvement rather than on the "acceptance of human limits." The fact that it takes into account the ethical dimension of humanity as a crucial issue is another reason for choosing to work within this renewed theoretical framework.

Therefore, my aim in this paper is to offer a humanist reading of Coriolanus on the basis of the character's limitations as a human being. In order to do so, I will also support my analysis of selfidentity in Coriolanus by drawing on recent criticism on community theory. Some of the concepts that will be handled in this assessment of the problematic notions of humanity, individual subjectivity and the relationship between the singular being and community in Coriolanus are inspired by Jean-Luc Nancy's The Inoperative Community (1991). I will also consider the concepts of "state or exception" and "homo sacer" as developed by Giorgio Agamben (1998) in analysing Coriolanus' position in Rome, as well as the ideas of loss and vulnerability that Judith Butler (2006) brings about in her discussion of "bare life," which are necessary to add an ethical dimension to the discussion on humanity. Finally, I will take on a relevant distinction made by Roberto Esposito (2012) between political and ethical communities to argue for Coriolanus' "singularity" as based on the recognition of his being just a vulnerable creature. These authors share an understanding of individual subjectivity which does not fulfil the human desire for self-sufficiency and transcendence but rather an inevitable, selfdestructive bond with community.

\section{Identity as a relational concept}

Generally speaking, Shakespeare's heroes are promising figures that believe in their capacity for self-fashioning but end up yielding to external forces that compel them to act in ways that prove to be devastating for the subject. It is the dialectical struggle between contradictory versions of the self what makes most of Shakespeare's tragic heroes such appealing characters. Brecht deemed them "inconsistent and relative, and hence more like life, where the development depends on contradiction" (Heinemann 1994, 232). As cultural materialism has shown, the main reason is that the 
Renaissance was a period offering greater possibilities to cultivate individualism and inwardness, fostering at the same time serious doubts about the sovereignty of the individual and the boundaries of the subject.

Dollimore points out that "Jacobean tragedy challenged Christian essentialism, and indeed its stoic and humanist derivatives" (1989, 156). So, Shakespearean drama, and in particular Coriolanus, is in this regard a prototypical product of the early modern period for it underscores the question of modern subjectivity by testing the degree of autonomy of the subject and its position in relation to other beings. As Kuzner points out in his essay on Coriolanus, "questions about selfhood were increasingly turning into questions about bounded selfhood" (2007, 175).

Shakespeare's tragedy dramatizes the rise and fall of Martius Caius, an arrogant patrician brought up by his mother to become the greatest warrior in Rome. Having built his reputation on countless battles since his adolescence, the Roman warrior reluctantly accepts the self-serving praise after his victory at Corioli (1.9.13-15). Coriolanus finds it unbearable having to beg for the people's support to be elected consul, certain as he is of his innate superiority and his martial virtue, and uncomfortable with the political manoeuvring of the patricians and the tribunes.

Coriolanus' discernment of his self-identity implies an assertion of his uniqueness. He identifies himself with absolute values which clash with the limitations he identifies in the plebeians. Coriolanus claims to be a complete, self-ruling being. Throughout the first three acts, he repeatedly insists on his autonomy and defines himself by openly declaring his hatred of the plebeians. In contrast to the idea of bounded selfhood and the absolute values he identifies with, Coriolanus associates the plebeians with ideas of mutability and corruption: "For|the mutable, Rank-scented meinie. Let them | Regard me, as I do not flatter, and|Therein behold themselves" (3.1.66-68); and he attacks them for their unreliability: "Trust ye? | With every minute you do change a mind $\mid$ And call him noble that was your hate, | Him vile that was your garland [...]" (1.1.164-67). Nor is he able to perceive the plebeians as discrete individuals but as a Hydra, the nine-headed monster (3.1.94). The metonymical reduction of the plebeians to mere "voices," "bodies" without a heart (2. 3. 190-91), and "tongues," and of the tribunes to "their mouths" 
(3.1.37) is further evidence of his inability to admit in others the subjective potential he claims for himself. To Coriolanus the people lack the distinctiveness that would allow them to claim an autonomous subjective identity. Coriolanus' use of degrading language to address the plebeians - "Go get you home, you fragments" (1.1.206) - highlights his conviction that they do not qualify as human beings, since they are perceived as a disjointed, shifting mass with no individual personality. This dehumanisation is also palpable in the analogy he draws between the plebeians and the lowest ranks in the animal kingdom: "What would you have, you curs, | That like nor peace nor war? [...] He that trusts you, |Where he should find you lions finds you hares, |Where foxes, geese you are [...]"(1.1.151-55). In contrast, he pictures Aufidius, his rival and the only character he identifies with, as the noblest of beasts, "a lion | That I am proud to hunt" (1.1.217-18).

However, the interpretation of Coriolanus' identity does not only rely on the stubborn assertion of physical and figurative boundaries of the self. As historicists have asserted, identity is also dependent on a shared view of what constitutes the subject, so Coriolanus' own identity is determined by how the concept of "virtue" is construed. In early Latin virtus denoted the quality entailed by being a vir (man), so it was typically associated with courage and military achievement. Yet later the term came to be associated with the Hellenic concept of arête $(\square \rho \varepsilon \tau \square)$, denoting goodness or excellence, of any kind, especially of manly qualities. ${ }^{4 \cdot}$ In Shakespeare's play the word is loaded with a range of meanings that must be negotiated and it may thus be interpreted in different ways depending on who speaks.

Everyone in Rome associates Coriolanus with the one quality in which he excels, military prowess. Yet, in the eyes of the people this virtue is also coupled with an excessive pride, depriving the warrior of the dignitas (worth) he considers his greatest asset:

FIRST CITIZEN I say unto you, what he hath done famously, he did it to that end. Though soft-conscienced men can be content to say it was for his country, he did it to please his mother and to be partly proud, which he is, even to the altitude of his virtue.

\footnotetext{
${ }^{4}$ For further discussion on the Roman concept of "virtue," its origin and evolution, see the first three chapters of McDonnell's Roman Manliness: Virtus and the Roman Republic (2006).
} 
SECOND CITIZEN What he cannot help in his nature you account as vice in him. You must in no way say he is covetous. (1.1. 27-32)

This discussion of Coriolanus' virtue continues in act 2 . In an attempt to offset the widespread condemnation of the haughty warrior, Cominius eulogizes Coriolanus in order to obtain the citizens' support in the election for consulship: "[...] he covets less | Than misery itself would give, rewards $\mid$ His deeds with doing them, and is content| To spend the time to end it" (2.2.120-23). Cominius insists on dissociating Coriolanus from an idea of excessive ambition since the term "virtue" in the republican era includes manliness and military courage but also honourability to qualify for public service (McDonnell 2006). Although it is the Roman custom, Coriolanus refuses to show his scars in public to ingratiate himself with the people:

MENENIUS It then remains

That you speak to the people.

CORIOLANUS I do beseech you,

Let me o'erleap that custom, for I cannot

Put on the gown, stand naked, and entreat them

For my wounds' sake to give their suffrage. Please you

That I may pass this doing

SICINIUS Sir, the people

Must have their voices, neither will they bate

One jot of ceremony. (2.2.128-36)

In Coriolanus' view, exhibiting the wounds and trading the people's support for his "mild words" implies disowning his true self. He is accustomed to wearing a sword but has not been trained in the art of rhetoric and lacks the capacity to effectively address others or be moved by the speech of others. From this perspective, it is Coriolanus' virtus in the wider sense of the term and his failure to display it in public that generates an excruciating tension in the character.

It is Coriolanus' assumption that his nobility is inherent to his nature and not dependent on the citizens' judgement. The conflict arises from a disagreement with what constitutes virtue and whether this is an inalienable feature of the subject, as Coriolanus contends, or not. 
Forced to beg the people and convince them of his own natural worth, Coriolanus asks his mother: "Why did you wish me milder? Would you have me |False to my nature? Rather say I play| The man I am" (3.2.14-16). Volumnia's reply,"O, sir, sir, sir, | I would have had you put power well on | Before you had it worn it out" (3.2. 1618), reveals how differently mother and son understand Coriolanus' virtue and how each of them perceives Coriolanus' identity. While Coriolanus equates it with military prowess, Volumnia assesses her son's virtus also in a political sense, as public service (Dollimore 1989, 221). In fact, the patricians see Coriolanus as an agent to serve the interests of their social class. In this respect, Volumnia's and Coriolanus' interpretation of true nobility and what constitutes Coriolanus identity are radically opposed. While Coriolanus insists on asserting his inherent virtus and his belief in the possibility "to stand |As if a man were author of himself | And knew no other kin" (5.3.35-37), there are many hints as to the fact that his identity as well as his power are not essential qualities to his being, but are now bound up with his capacity to act politically.

It is not only Coriolanus' identity that is defined in an intersubjective manner. Similarly, the patricians' identity is determined by their abuse of the plebeians. Yet, while other members of his class have understood the usefulness of politics and the need to comply with state law, Coriolanus, chosen to represent patrician authority in their struggle for supremacy, refuses to act politically: "Must I with my base tongue give to my noble heart $\mid \mathrm{A}$ lie that it must bear? (3.2.100-102). Coriolanus' naive question underscores the fact that his worth in Rome is defined in an intersubjective manner. Volumnia and the other patricians are aware of the fact that Coriolanus' military virtue is not enough to prove his worth. Despite Volumnia's attempts to persuade her son of the honourability of humbling oneself in public ("I would dissemble with my nature where|My fortunes and my friends at stake required |I should do this in honour." (3.2.63-65), to Coriolanus acting politically implies submitting to an unbearable act of violence: relinquishing his own nature. His unalienable essence and his autonomy are being attacked. Admitting the political dimension of his identity would turn Coriolanus into a political pawn of the Roman state. Coriolanus' disdainful references to play acting, especially in 3.2, signal the character's resistance to renouncing his individual sovereignty. 
In his interpretation of Coriolanus, Dollimore remarks (1989, 229) on the constructedness of subjectivity against the essentialist notion of the self that Coriolanus defends, and which humanist critics have underlined as the redeeming feature of the Roman warrior. Coriolanus' naive principles about moral and ethical integrity are shattered by his mother's political awareness. Volumnia perfectly understands the social and political nature of self identity since Coriolanus' reputation, and as a result his power in Rome, no longer depends on his courageous actions on the battlefield but mainly on the recognition of his merits by the citizens of Rome. Consequently, when Coriolanus uses his power against Rome "there emerges a contradiction which reveals both reputation and state to be prior to and in some sense constitutive of virtus" (Dollimore 1989, 218). As a result, Coriolanus' final destruction seems unavoidable, for he conceives his place in the world in terms of absolute values. In fact, Coriolanus fears the dissolution of his own self if the patricians mingle with the fragmented, shapeless mass of plebeians: "[...] my soul aches|To know, when two authorities are up,|Neither supreme, how soon confusion | May enter 'twixt the gap of both and take|The one by th'other" (3.1.109-12). However, to the more politically-minded patricians the absolute has already been displaced by a "social network of relative interactions, one in which intervention not essence is determining" (Dollimore 1989, 219).

Yet, after his expulsion from Rome Coriolanus still declares "There is a world elsewhere" (3.3.137), believing in the myth of innate worth and self-autonomy of the subject and the possibility of surviving outside Rome. However, Aufidius' failure to recognise his enemy provides new evidence that self-identity and social recognition are thus inextricably related. Neither Aufidius nor his men can recognize their arch-enemy because the network of social and power relationships that served to determine his identity in Rome has collapsed. As a result, Coriolanus turns into an anomic subject outside Rome:

AUFIDIUS Whence com'st thou? What wouldst thou? Thy name?

Why speak's not? Speak man. What's thy name?

CORIOLANUS

If, Tullus,

Not yet thou know'st me, and seeing me dost not

Think me for the man I am, necessity

Commands me name myself. (4.5.50-54) 
Coriolanus ingenuously equates his identity with his name, wrongly assuming that those are inalienable properties of the subject. ${ }^{5}$ Yet, the Volsces can only identify the man as their most feared adversary. The name given to him by Rome for his service allows for the recognition of the anonymous individual as the heroic figure that "l[ed] them like a thing|Made by some other deity than Nature, | That shapes men better" (4.6.91-93). Yet, alienation from Rome dispossesses the man of his socially constructed identity which, in Dollimore's view $(1989,229)$, is the only identity that is meaningful. The events in acts IV and V provide further evidence that without Rome Coriolanus' identity becomes unstable.

The incongruity of Coriolanus' self-proclaimed absoluteness becomes more visible when he attempts to harmonize his contrary allegiances after having joined the Volsces, where he contemplates his situation in the soliloquy pronounced at the doors of Antium (4.4.12-24). The oxymoronic combinations in "My birthplace hate I, and my love's upon|This enemy town" (4.4.23-24) expose the internal inconsistencies of a literally dislocated character. Further evidence of the inevitable collapse of what Coriolanus assumes to be his essential nature appears in act 5. Although he has claimed to be loyal to his former adversaries, he finally spares the Romans and betrays Aufidius, feeling compelled to confirm his reputation among his men: "You must report to th' Volscian lords how plainly|I have borne this business" (5.3.3-4). At this point, Coriolanus' identity has been dashed to pieces. His capitulation to the citizens of Rome lays bare the inconsistencies of an absolute, fixed self. First of all, it is impossible to claim to be both a Roman and a Volscian warrior at the same time. Moreover, it is his agreeing to negotiate a peace agreement that invalidates his claim to an essentially unalterable martial nature. I agree with Dollimore that "Coriolanus [...] is constituted by the contradictions inherent in the martial ideal: though identified in terms of an innate superiority he is in fact the ideological effect of powers antecedent to and independent of him" $(1989,218)$. Sicinius' remark about the sudden alteration of "the

\footnotetext{
${ }^{5}$ Calderwood (1966) discusses the radically opposite connotations evoked by the name of "Coriolanus." While for the warrior, the name has "his own private meaning and remains true to that, to his own conception of nobility" (219), events prove that in actual fact "Coriolanus" is not the property of the man, but a name given by the people of Rome, endowed with public meaning, and hence a symbol of Roman pride and reputation.
} 
condition of man" (5.4.10) seems to contest the immanence of virtue and the inalterability of the subject's identity.

The play, as Dollimore suggest, is concerned with the fact that self-identity is determined by historical contingency and change $(1989,229)$. As Coriolanus' final concession proves, his identity is determined by external circumstances, and, I would further argue, by the nature of the ethical relationships he eventually establishes with the other. As Dollimore's politically-oriented reading suggests, Coriolanus ends up succumbing to the power of external elements competing for his loyalty. It is that surrender of the character, which Dollimore essentially deems as acceptance of "civic duty" and the emergence of political awareness that I intend to examine in the next section of this essay.

I will now consider the Roman play from a slightly different perspective, congruent with the materialist scepticism about claims to subjective autonomy I have outlined, but also taking into account theoretical developments on community theory and the area of biopolitics.

\section{Ethical engagement with the "other": the singular being and community in Coriolanus}

As with most other classical plays, the main source for the story of Coriolanus was Thomas Norton's famous translation of Plutarch's Lives of the Noble Grecians and Romans (1595). ${ }^{6}$ Since it was the exemplary nature of the tales that made this ancient material especially valuable to writers of the early modern period, I contend that Shakespeare pictured the Roman warrior as a dignified figure, although not so much for his pretensions to superiority and selfintegrity but, as I will argue, just for the opposite - the character's vulnerability. In my view, it is the ethical gesture of opening up to community in the face of the impending finitude of other beings that makes Coriolanus such a model of humanity, despite claims to the contrary. Therefore, in the final part of my essay I intend to support an ethical reading of Coriolanus that complements cultural materialist

\footnotetext{
${ }^{6}$ Bliss states that Shakespeare probably followed the 1595 edition with some changes "in the expanded roles of Menenius, Volumnia, the tribunes and Aufidius, all of whom become not only actors but commentators on the protagonist" $(2010,10)$.
} 
interpretations of this tragedy. My reading focuses on the nature of the "singular being" and the "inoperative community" as argued by Nancy (1991). Following Butler's analysis of vulnerability as the ethical basis on which to define humanity, I contend that Coriolanus is a worthy epitome of humanity as he makes the ethical choice of entering a community of vulnerable and mortal beings in act 5. As will be argued, this engagement with other exposed, finite beings is only possible in a situation of discourse where singular beings communicate and share their human limitations as common loss.

As argued above, the illusion of boundedness of the subject actually collapses when Coriolanus faces his closest kin who make a plea for mercy. Coriolanus' interlocutors are thus exposed as mortal beings. This revelation of the others as finite individuals thrusts Coriolanus to the limits of a community where all beings share something in common, their being equally vulnerable and finite.

Yet, in order to properly justify this statement, I must first clarify what exactly is the nature of community presented here. What community means, and whether its existence is possible at all, is a question to which several thinkers have offered responses, which has resulted in an engaging body of literature in the area of biopolitics with profound ethical implications. Thus, Nancy in "The Inoperative Community" (1991) has come to the conclusion that the idea of community is a broken myth from which society materialized. Nancy claims that the existence of community is a utopian ideal and as such unfeasible. Instead "community, far from being what society has crushed or lost, is what happens to us -question, waiting, event, imperative- in the wake of society"(11). Therefore, it is rather the thought of community that comes about as a result of the drive for human transcendence and immortality, as the possibility of fusion with others. Yet, to Nancy such possibility is delusive because we all tend to assert our being, even if we wish "to be" in common with others:

Community is what takes place always through others and for others. It is not the space of the egos — subjects and substances that are at the bottom immortal- but of the I's, who are always others (or else nothing). If community is revealed in the death of the others it is because death itself is the true community of I's that are not egos. It is not a communion that fuses egos into an Ego or a higher We. It is the community of others. The genuine community of mortal beings, or death as community, establishes their 
impossible communion. Community therefore occupies a singular place: it assumes the impossibility of its own immanence, the impossibility of a communitarian being in the form of a subject. In a certain sense community acknowledges and inscribes - this is its peculiar gesture- the impossibility of community. (1991,11)

Nancy's community is inoperative because it does not fulfil the natural desire for immanence and transcendence; quite the opposite, it undoes the subject. Subjectivity as autonomy from others and selfcontainment, as Coriolanus intends it to be, vanishes within society as well as within community, for the "being-in-community" is no longer in possession of his own self but somehow loses himself to others. As argued above, Coriolanus' insistence on distinguishing himself from others, on claiming full agency, makes him believe in the possibility to "author himself." Hence, he despises the idea of community, of being in common with others, with all, except with Aufidius.

At first sight, it would seem that it is Coriolanus' obstinacy and his non-compliance with Roman custom that brings about the warrior's self-alienation. However, I would argue, following Nancy's understanding of community, that even when he is acknowledged in Rome for his military achievements, he is not yet a "singular" being or a "being-in-community." The events in acts 1 to 3 show that what operates in Rome is a society of interest in which the supreme law of the state is imposed over the rights of individual subjects. Coriolanus' refusal to show his scars -visible signs of his vulnerability-confirms the character's lack of awareness of the self as a member of a community of interest that we call society. Instead, convinced of his innate superiority and self-sufficiency, Coriolanus claims independence of Roman citizenship, rebels against any form of subjection, and resists the law of that community. Coriolanus' selfassertion generates a perverse "state of exception" by virtue of which the law may be applied not to protect individual sovereignty but just to reduce it in favour of the preservation of the commonwealth. The concept of state of exception is developed by Giorgio Agambem in Homo sacer: Sovereign Power and Bare Life (1995) to account for Nazi totalitarianism, but this being a notion worked out from the analysis of the archaic Roman figure of the homo sacer, I agree with Kuzner (2007) that it may be suitably applied to Coriolanus' situation in Rome. The banishment forces Coriolanus to abandon the community of Rome but even before that Coriolanus is a homo sacer, a "human 
life [...] included in the juridical order solely in the form of its exclusion (that is, of its capacity to be killed)" (Agambem 1998, 12). Coriolanus may still be alive but he is politically excluded from Roman life, from qualified life as opposed to bare life.

Even after being expelled from Rome, Coriolanus insists on the need to "stand, $\mid$ As if a man were author of himself $\mid$ and knew no other kin" (5.3.35-36) on the assumption that to be virtuous is "to be obstinate" (5.3.26). Yet, it is right after being addressed by Virgilia that Coriolanus manages to control the narcissistic instinct that compelled him to claim his singularity on the basis of his "innate" superiority and self-autonomy. It is precisely in 5.3 that Coriolanus starts to approach the community by opening his being to it.

Throughout the play several characters, including Coriolanus himself, portray the Roman warrior as an invulnerable being, "a thing of blood," a "God that leads the Romans," highlighting his "natural" inhumanity. Perhaps this should be viewed as a defensive strategy by Coriolanus to avoid political subjection, since undergoing exposure would involve recognizing the sovereignty of the state over that of the individual, and hence, admitting that his life in Rome is "bare life." The awareness of such limitations to his citizenship and his free will provokes an obvious resistance to the law on Coriolanus' part and his eventual banishment from Rome. The notion of bare life, developed by Agambem in his discussion of homo sacer (1995), is closely related to that of "precarious life" in Butler's work (2006). In a deep and insightful reflection on the role of the Humanities at present, Butler advocates an ethics of non-violence as a new form of humanism and guiding principle for our being members of a community called humanity.

Thus if we read Coriolanus closely against this notion of bare or precarious life, it becomes obvious that from a political point of view Coriolanus' life is in fact nothing other than subjection to the state: in Rome he is not a sovereign subject, free to choose his own course of action, as events prove. Having been framed as a warrior, he is serviceable as a weapon against Rome's adversaries. As a matter of fact, he is metonymically identified with a sword that is employed to inflict violence on others. In Rome Coriolanus lives in a "state of exception" for the law limits his sovereignty by imposing on him obligations, some of which he is used to and willing to perform, but others -publicizing his wounds, which implies exposing his 
vulnerability as a mortal being - seem utterly unbearable. By resisting self-subjection to the law of Rome, he paradoxically becomes an enemy of Rome.

This reticence to admit his subjection also reveals a clear resistance, deafness to the appeal of otherness: "Wife, mother, child, I know not [...] Therefore begone.|Mine ears against your suits are stronger than |Your gates against my force" (5.2.76-83), he replies to Menenius' humble plea. Other critics (Calderwood 1966) have noted Coriolanus' failure to communicate effectively with others. ${ }^{7}$ However, this is not the result of speaking two different languages. In my view, this flaw in communication is patent not only when he confronts the citizens of Rome, whom he despises, but even when his friends and relatives address him. Yet, Coriolanus recoils from others. He does not wish to be in lieu of the Other so as to avoid being moved: "Fresh embassies and suits,|Nor from state nor private friends, hereafter | Will I lend ear to" (5.3.16-18). This open refusal to approach community, by idealistically asserting the subject's independence and denying human bonds, may again be read as a strategy for self-defence since the character avoids exposure of any kind, whether this be physical, verbal, or emotional. Being exposed to others implies in a sense accepting one's flaws, one's limitations. It is only when he listens to Volumnia's speech (5.3.131-82) that the appeal of the other does transform him, shattering Coriolanus' pretensions to self-containment. As Butler states:

The situation of discourse consists in the fact that language arrives as an address we do not will, and by which we are in an original sense, if not, in Levinas's terms held hostage. So there is a certain violence already on being addressed, given a name subject to a set of impositions, compelled to respond to an exacting alterity [...]. To be addressed is to be, from the start, deprived of will, and to have that deprivation exist as the basis of one's situation in discourse. (Butler 2006, 139)

\footnotetext{
7 Calderwood (1966) considers this failure derives from the differences between Coriolanus' "private language," which is used in a futile way to communicate, and hence the impossibility of a genuine verbal transaction between him and others. However, this interpretation focuses rather on Coriolanus' exchanges with the plebeians at large.
} 
Therefore, in his conference with the Roman embassy, being addressed as "son", "husband" and "father" Coriolanus is inadvertently pushed into community, admitting his bond to others. Esposito in Terms of the Political: Community, Immunity, Biopolitics $(2012,15)$ declares that "the law of community is inseparable from the community of law, debt, guilt." Volumnia readily reminds Coriolanus of his debt to others: "Say my request's unjust, |And spurn my back. But if it not be so, | Thou art not honest, and the gods will plague thee | That thou restrain'st from me the duty which |To a mother's part belongs" (5.3.164-68). As a result, when Coriolanus eventually tries to effect community by negotiating a peace treaty, that community "inevitably ends up turning it[self] into its exact opposite - a community of death and the death of community" (Esposito 2012, 15). As Coriolanus states, opening up to community necessarily entails an undoing of the subject, and hence death:

CORIOLANUS O mother, mother!

What have you done? Behold, the heavens do ope,

The gods look down, and this unnatural scene

They laugh at. O my mother, mother! O!

You have won a happy victory to Rome;

But for your son - believe it, O believe it -

Most dangerously you have prevailed,

If not most mortal to him. But let it come. - (5.3.183-9o)

By acknowledging the face and the grief of the Other -mother, wife, child-Coriolanus actually acknowledges what they share as members of the inoperative community - their being exposed to lack and loss. It is only then, when the seemingly imperturbable warrior comes to realise the vulnerability and finitude of his loved ones, that he comes to accept his own. It is only then that Coriolanus becomes, using Nancy's formulation, "a singular being in community." The martial self-bound Coriolanus admits his weakness: "Aufidius, though I cannot make true wars, I'll frame convenient peace. Now, good Aufidius, |Were you in my stead, would you have heard |A mother less? Or granted less, Aufidius?" (5.3.191-94)

Certainly, there are scholars who have already examined this tragedy from a communitarian perspective. Kuzner has argued that in Coriolanus the playwright "represents the birth of Roman republicanism as the birth of a state that, in the name of securing personal borders, uses law to place individuals outside the law thus 
making life within the city what Agamben calls 'bare life'" (2007, 173). For Kuzner the play advances the possibility of establishing a community "outside the state of exception, directing us toward a specifically sexual "world elsewhere'" (3.3.136). ${ }^{8}$ Although I can appreciate his argument, where he resorts to queer theory to assert the possibility of a community of gay outlaws, I propose instead that Coriolanus' singularity and coming into community is brought about "on the basis of vulnerability and loss" epitomized in the precariousness of life he perceives in Volumnia, Virgilia and his son, and by extension in the citizens of Rome.

In Precarious Life: Violence, Mourning and Politics Butler raises a central question that may help us to decide what humanity is all about and apply her notion to our interpretation of Coriolanus. In her discussion Butler enquires "who counts as human? Whose lives count as lives?" to conclude, echoing Hamlet, that "loss has made a tenuous 'we' of us all" (2006, 20). Accordingly, the idea of community would surface when we become conscious of our own human limitations and we share this sense of vulnerability with others:

This means that each of us is constituted politically in part by virtue of the social vulnerability of our bodies - as a site of desire and physical vulnerability, as a site of a publicity at once assertive and exposed. Loss and vulnerability seem to follow from our being socially constituted bodies, attached to others, at risk of losing those attachments, exposed to others, at risk of violence by virtue of that exposure. $(2006,20)$

And it is exposure precisely that Coriolanus shuns until the final act, when he confronts the impending death of his loved ones. It is in that instant that Coriolanus for the first time seems willing "to undergo a transformation", by making a crucial ethical choice. It is as a result of this choice that he becomes a singular being, possessed with a vulnerability, which makes him look the more human.

\footnotetext{
${ }^{8}$ Coriolanus does not really identify with anyone, except with his greatest rival, Aufidius. This is probably due to the fact that they have reached a point of identification, having been both physically exposed to one another in several battles. As a result, they may have come to recognise their own vulnerability and their common mortality. However, I do not perceive Aufidius' emerging awareness of community as recognition of finitude and vulnerability as I see it happening to the Roman warrior in the last act.
} 
To Coriolanus being dispossessed of self-autonomy and community seems at first a temporal condition and he believes that joining Aufidius and his men may afford him a new sense of belonging. In other words, when he joins his former enemies he does so thinking that somehow, as Butler states, "mourning will be over and some restoration of prior order will be achieved" $(2006,22)$. However, once deprivation is experienced, "something about who we are is revealed, something that delineates the ties we have to others, that shows us that these ties constitute what we are, ties and bonds that compose us" (22). For Butler, grief reveals a sense of "community of a complex order" and this is effected "by bringing to the fore the relational ties that have implications for theorizing fundamental dependency and ethical responsibility" (22).

Although Butler is concerned with the contribution of the Humanities to make the current world a more ethically responsible one, I consider her argument to be relevant to an ethical interpretation of this Shakespearean tragedy, one in which politics and ethics are brought to the fore. Therefore, I contend that it is a sense of ethical responsibility that makes Coriolanus abandon an ethics of war for an ethics of non-violence when he is begged to spare Rome. It is only in the last act that he assumes his dependency from community and his moral responsibility towards others, even if that entails self-annihilation.

As Butler points out, grief displays a challenge to the notion of self-contained beings because the body

implies mortality, vulnerability, agency: the skin and the flesh expose us to the gaze of others, but also to touch and violence, and bodies put us at the risk of becoming the agency and instrument of all of these as well. Although we struggle for rights over our own bodies, the very bodies for which we struggle are not quite our own. $(2006,26)$

Butler's words offer a glimpse of human nature much more despairing than essentialist humanism has offered in the past. What is posited here is the possibility of a humanist community that "affirms relationality not only as a descriptive or historical fact of our formation, but also as a normative dimension of our social and political lives, one in which we are compelled to take stock of our interdependence" $(2006,27)$. This assertion highlights the ethical dimension of the relationship of the individual self with the 
community and this, I think, is applicable to a communitarian interpretation of Coriolanus by suggesting non-military solutions against physical violence.

The final act of recognition of the Other, whose survival depends on an ethical act on Coriolanus' part, makes him approach community which, although inoperative for it crushes the human longing for transcendence and self-containment, presents the subject in its "singularity", as an admirable being.

Esposito, in trying to establish the difference between a political and an ethical community, points out that "care, rather than interest, lies at the basis of community. Community is determined by care, and care by community." Following Heidegger, Esposito claims that "the duty of community (providing, yet not conceding, that there is one) is not to liberate us from care, but instead to protect it as the sole thing that renders community possible" $(2012,26)$. The type of care he is referring to is not a concern for self-survival but "care for the other", which entails being open to otherness. This is the only instance in which community may accordingly be fulfilled.

Wishing the possibility of an ethical community to come true, Butler also identifies the recognition of the other- what Esposito calls "care for the other"- as the only possible foundation for community to exist. Certainly, Coriolanus is involved in a situation "that dislocates [him] from his former position, [his] subject-position, and allows [him] to see that community itself requires the recognition that we are all, in different ways, striving for recognition" (Butler 2006, 44).

\section{Conclusion}

An ethical reading of this late Shakespearean tragedy encourages an understanding of human nobility and virtue as "singularity of being." As has been noted, the singular being is one who accepts his own vulnerability and humanity by virtue of perceiving his own finitude and that of others. Therefore, this humanist interpretation of Coriolanus seems to me utterly compatible with the cultural materialist reading Dollimore endorses, for it allows us to understand subjectivity as a problematic notion, by combining a political with an ethical analysis of subjectivity and community. As 
Dollimore points out, the character of Coriolanus is decentred by contingent forces which make the self unstable. His being a member of Roman society deprives him of his individual sovereignty and makes of him a homo sacer leading a bare life.

However, I would further argue that far from being an epitome of inhumanity as most characters remark, what is stressed in this process of dislocation of the subject is, above all, his own vulnerability and his limitations as a human being. The character of Coriolanus is revealed as a worthy figure mainly because he discards the myth of transcendence and humbly accepts his own precariousness as a mortal human being. At the end of the play, Coriolanus is no longer the absolute being other characters as well as he himself have asserted him to be. By opening up to the address of others and recognizing their precariousness Coriolanus turns into a caring, compassionate being. This entails a painful process of identification with utter loss and grief which takes places in the closing act. The meeting with the Roman embassy reveals his weakness - he cares for the Other. So even though Coriolanus has claimed freedom from community, the fact is that he is moved by the exposure, the vulnerability and the potential loss of other beings. Consequently, he makes a responsible choice to recognize his bond to the inoperative community which eventually turns out to be a self-destructive move. It is only when the being is moved by equally exposed and vulnerable beings that the inoperative community emerges and Coriolanus' singularity of being is finally disclosed.

Esposito further argues that the political and the ethical community are not one. "Politics is not a widening but a reduction of freedom, and such is a consequence, not a contradiction, of the absoluteness of freedom itself. This is precisely because the essence of freedom resides in being unlimited, and the task of politics is to limit freedom with its opposite-an irresistible power" $(2012,21)$. While Coriolanus rejects the idea of being in the political community, he nevertheless comes to accept his share in an ethical one where moral choices are available to the singular being. In this sort of community or "being-in-common" Coriolanus can choose between preserving his own life or, alternatively, caring for others by accepting impending death at the hands of the Volsces. The transformation the character undergoes reveals that, after all, being in community is what makes beings more human, and that human 
care and recognition of the other are the ethical bases of such community.

\section{References}

Agambem, Giorgio. 1998 (1995). Homo Sacer: Sovereign Power and Bare Life. Standford: Standford University Press.

Arnold, Oliver. 2007. The Third Citizen: Shakespeare's Theatre and the Early Modern House of Commons. Baltimore: John Hopkins University Press.

Belsey, Catherine. 1980. Critical Practice, London: Routledge.

Bliss, Lee. 2010. "Introduction." William Shakespeare, Coriolanus. 1-121. Cambridge: Cambridge University Press.

Bradley, A.C. 1991 (1904). Shakespearean Tragedy: Lectures on Hamlet, Othello, King Lear, Macbeth. London: Penguin.

Butler, Judith. 2006. Precarious Life: The Powers of Mourning and Violence. New York: Verso.

Calderwood, James. 1996. "Coriolanus: Wordless Meanings and Meaningless Words." SEL: Studies in English Literature, 1500-1900 6: 211-224.

Dollimore, Jonathan. 1989 (1984). Radical Tragedy: Religion, Ideology and Power in the Drama of Shakespeare and his Contemporaries. Hempstead: Prentice Hall.

Esposito, Roberto. 2012. Terms of the Political: Community, Immunity, Biopolitics. Translated by Rhiannon Noel and introduction by Vanessa Lemm. New York: Fordham.

Goddard, H. C. 1960 (1951). The Meaning of Shakespeare, vol. 2, University of Chicago Press: London.

Hadfield, Andrew. 2005. Shakespeare and Republicanism. Cambridge: Cambridge University Press.

Heinemann, Margaret. 1994. "How Bretch Read Shakespeare." In Political Shakespeare: Essays in Cultural Materialism, edited by Jonathan Dollimore and Alan Sinfield, 226-255. Manchester: Manchester University.

Knight, G. Wilson. 1947. The Crown of Life: Essays in Interpretation of Shakespeare's Final Plays. London: Methuen.

- 1995 (1930). The Wheel of Fire: Interpretations of Shakespearean Tragedy with Three New Essays. London: Routledge.

Kuzner, James. 2007. "Unbuilding the City: Coriolanus and the Birth of Republican Rome." Shakespeare Quarterly 58 (2):174-199.

McDonnell, Myles. 2006. Roman Manliness: Virtus and the Roman Republic. Cambridge: Cambridge University Press. 


$$
\text { (E) ederi } 26 \text { (2016) }
$$

Mousley, Andy. 2007. Re-Humanising Shakespeare: Literary Humanism, Wisdom and Modernity. Edinburgh: Edinburgh University Press.

Patterson, Annabel. 1989. Shakespeare and the Popular Voice. Oxford: Basil Blackwell.

Nancy, Jean-Luc. 1991. The Inoperative Community. Edited by Peter Connor. Minneapolis: University of Minnesota.

Shakespeare, William. 2010 (1623). Coriolanus. Edited by Lee Bliss. Updated edition. Cambridge: Cambridge University Press.

How to cite this article:

Pascual Garrido, María Luisa. "Re-humanising Coriolanus: Community and the ethical self." SEDERI 26 (2016): 85-107.

Author's contact: ffipagam@uco.es

Postal address: Dpto. Filologías Inglesa y Alemana - Facultad de Filosofía y Letras Plaza Cardenal Salazar s/n - 14071 Córdoba, Spain 